\title{
41HS144, A Middle Caddo Period Settlement and Cemetery in the Sabine River Basin of East Texas
}

Timothy K. Perttula

Heritage Research Center, Stephen F. Austin State University

Follow this and additional works at: https://scholarworks.sfasu.edu/ita

Part of the American Material Culture Commons, Archaeological Anthropology Commons, Environmental Studies Commons, Other American Studies Commons, Other Arts and Humanities Commons, Other History of Art, Architecture, and Archaeology Commons, and the United States History Commons

Tell us how this article helped you.

This Article is brought to you for free and open access by the Center for Regional Heritage Research at SFA ScholarWorks. It has been accepted for inclusion in Index of Texas Archaeology: Open Access Gray Literature from the Lone Star State by an authorized editor of SFA ScholarWorks. For more information, please contact cdsscholarworks@sfasu.edu. 


\section{HS144, A Middle Caddo Period Settlement and Cemetery in the Sabine River Basin of East Texas}

\section{Creative Commons License}

\section{(c) (1) \&}

This work is licensed under a Creative Commons Attribution-NonCommercial 4.0 International License 


\title{
41HS144, A Middle Caddo Period Settlement and Cemetery in the Sabine River Basin of East Texas
}

\author{
Timothy K. Perttula
}

\section{INTRODUCTION}

Site 41HS144 is a Middle Caddo period (ca. A.D. 1200-1450) settlement and cemetery in the Sabine River basin in the East Texas Pineywoods (Figure 1). The site was excavated by collectors, including Mr. Red McFarland, a well-known collector and looter of Caddo burials, in the mid-1970s. McFarland provided to the Texas Archeological Research Laboratory at The University of Texas at Austin (TARL) basic information on the site and the cultural features that he and other collectors found there, and he also donated to TARL a collection of recovered artifacts. This article is an analysis of the available records and collectors from $41 \mathrm{HS} 144$.

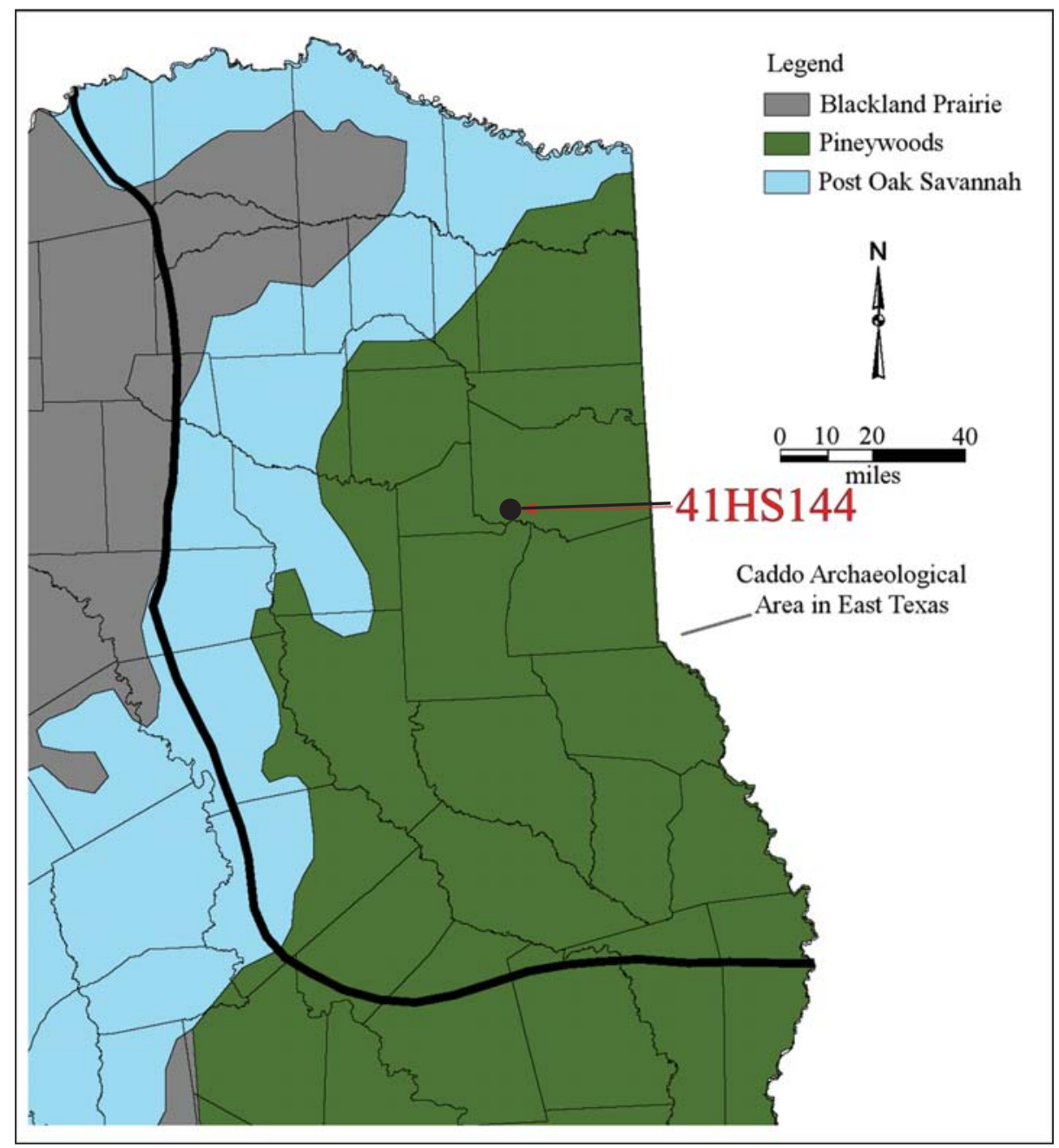

Figure 1. Location of 41HS144 in East Texas. 


\section{SITE SETTING AND CULTURAL FEATURES}

The site is situated on a sandy knoll overlooking the Clarks Creek floodplain to the north, and the broader floodplain of the Sabine River to the east and south (Figure 2). Clarks Creek is a southward-flowing tributary to the Sabine River in the mid-Sabine River basin. 41HS144 is about $15 \mathrm{~km}$ west of the Pine Tree Mound site (41HS15) (Fields and Gadus 2012:Figure 9.9), and is in the territory of the Pine Tree Mound community (Fields and Gadus 2012:Figure 9.10).

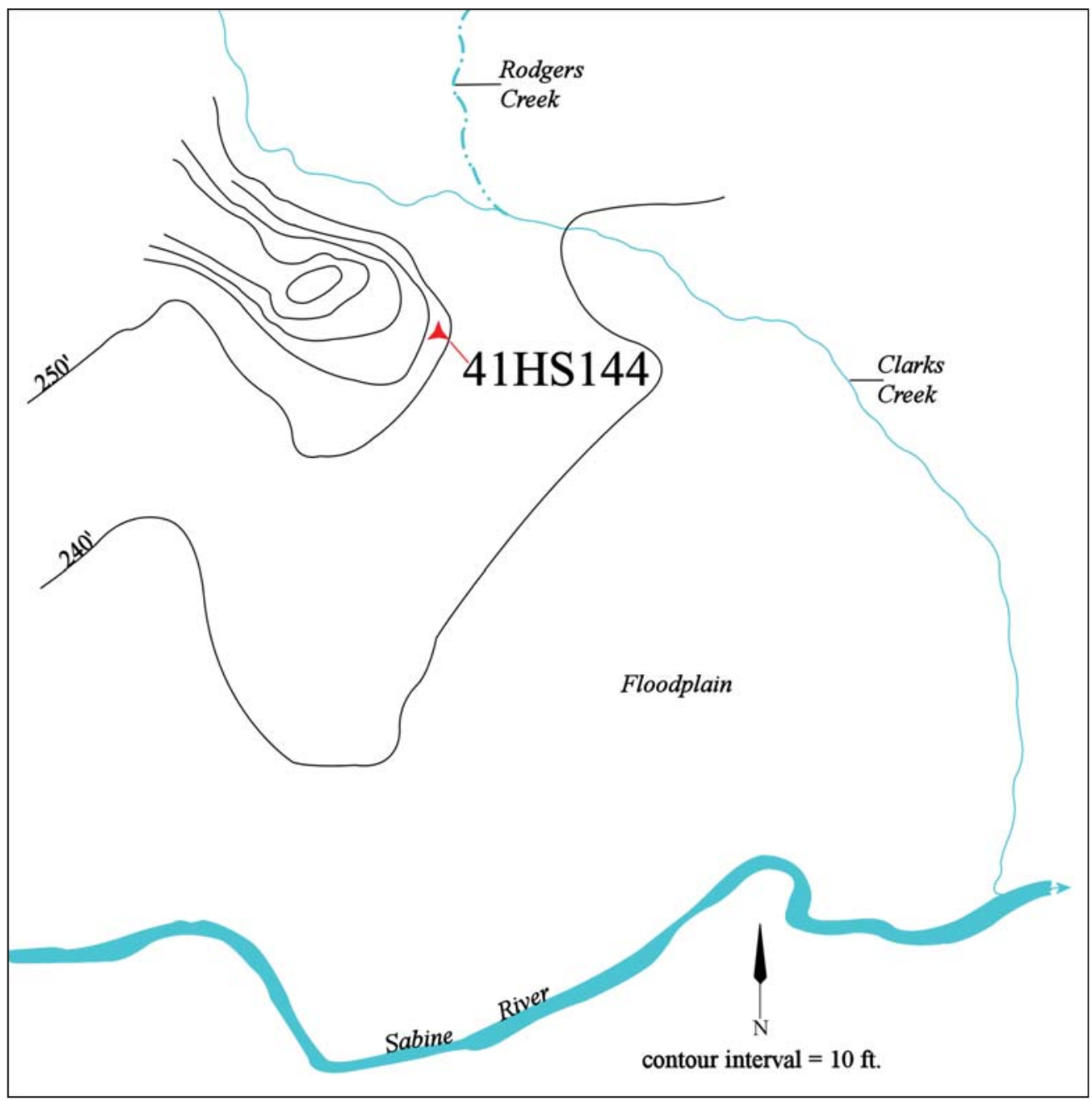

Figure 2. The setting of 41HS144 in the Sabine River valley, Harrison County, Texas.

The investigations at 41HS144 indicate that it had a complex intra-site organization. Apparently three circular Caddo house structures and one rectangular structure were identified and excavated at the southern and western parts of the settlement (Figure 3), along with three extensive areas of habitation deposits (with ceramic sherds and lithic artifacts) between two structures as well as north and east of the two northernmost Caddo structures. Finally, there is a Caddo cemetery in the southeastern part of the settlement (Figure 3).

The Caddo cemetery at 41HS144 is in area ca. $13.1 \mathrm{~m}$ northeast-southwest and $12.2 \mathrm{~m}$ northwestsoutheast (Figure 4). The 18 grave pits are oriented northwest-southeast, like other Caddo burials in the Pine Tree Mound community (Fields and Gadus 2012:Figure 5.35), with at least two rows of burials with between 6-8 individuals per row. The beginnings of two other rows at the northern end of the cemetery had two individuals per row. Although no information was provided by the collectors concerning the orientation 


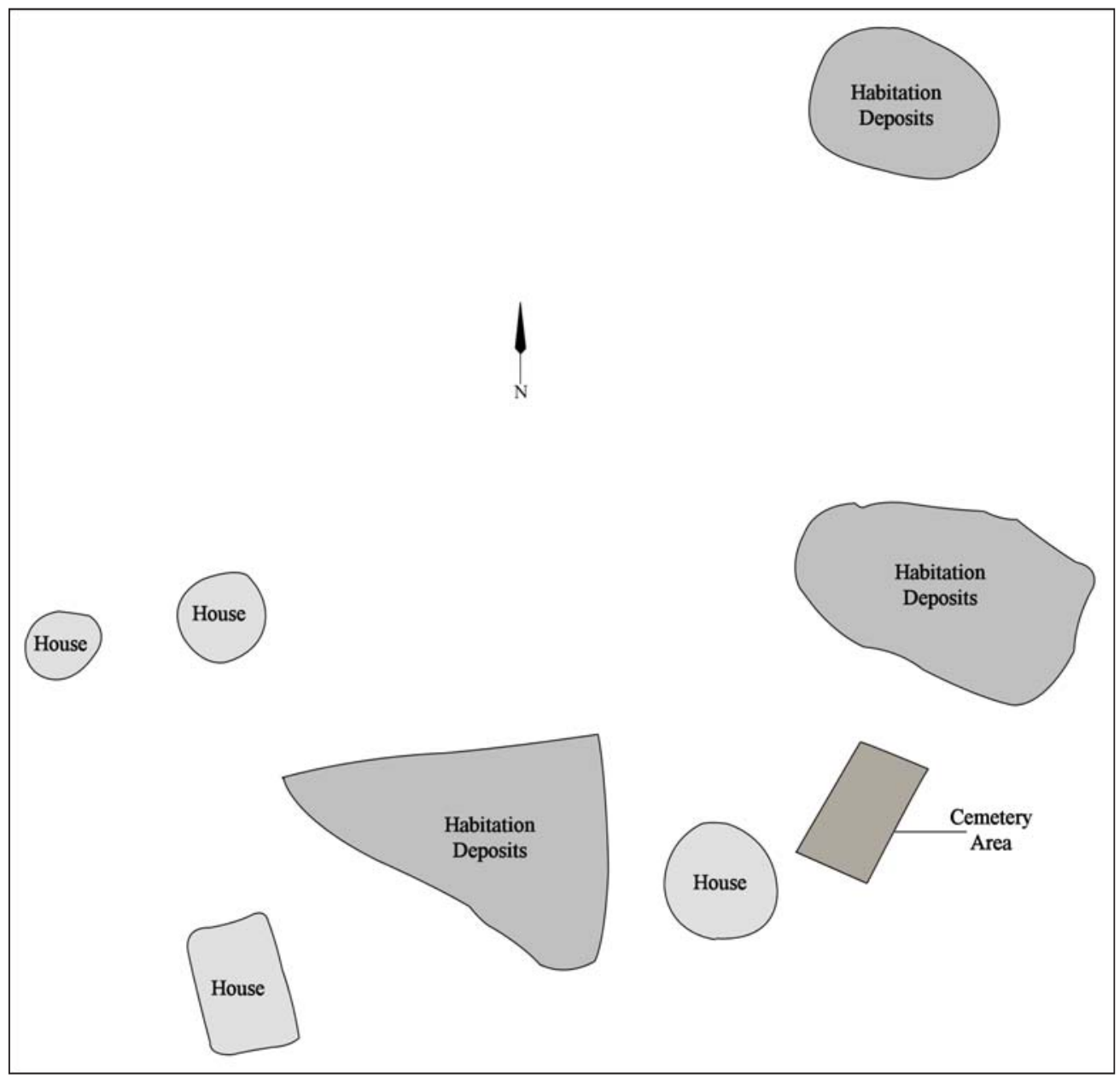

Figure 3. Plan of cultural features at 41HS144.

of the deceased in the burial pits, it is likely they were laid in an extended supine position of the pit floor, with their heads facing to the northwest, comparable to other Pine Tree Mound community Caddo burials.

The burials ranged widely in size (see Figure 4), suggesting that perhaps both adults and children/ adolescents were buried in the cemetery. It is possible that the larger burial pits in the southern row had two individuals buried in these graves. The larger burial pits $(n=6)$ were also deeper, ranging from 1.2-1.8 $\mathrm{m}$ in depth, while the 12 smaller burial pits were only ca. 46-61 cm in depth. The contents of these burial features are not known, unfortunately.

\section{ARTIFACT COLLECTION}

The artifact collection from 41HS144 at TARL is primarily comprised of ceramic sherds from plain ware $(n=177)$, utility ware $(n=275)$, and fine ware $(n=33)$ vessels. There are also a few lithic tools and miscellaneous clay artifacts. There is no information available regarding whether this collection comprises a representative sample of the material culture in the habitation deposits at the site. 


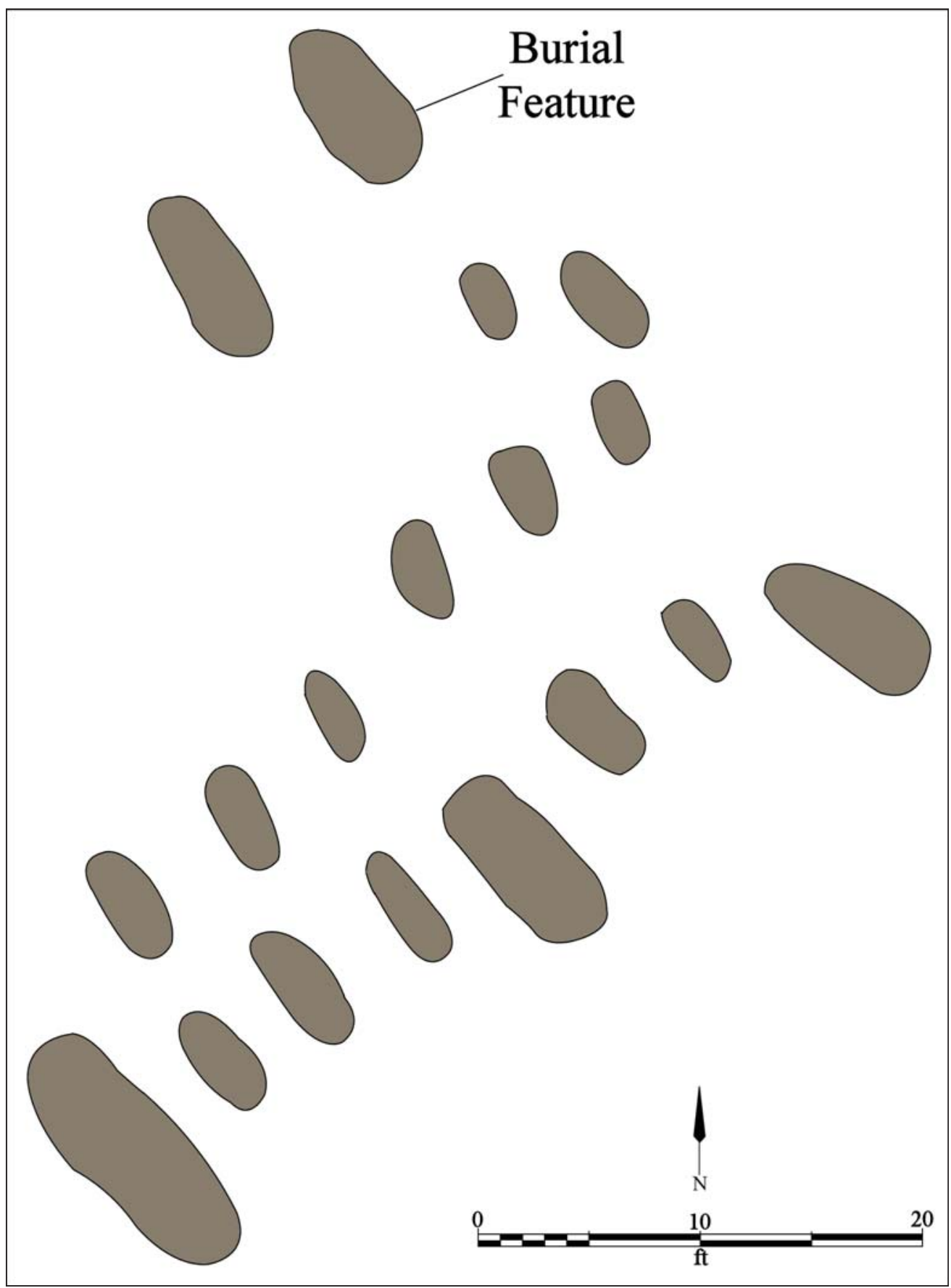

Figure 4. Plan of the burial features in the Caddo cemetery at 41HS144.

\section{Lithic Artifacts}

The lithic artifacts in the TARL collection include both chipped and ground stone tools. The chipped stone artifacts are two biface fragments made from local petrified wood and quartzite raw materials. There is also a Ouachita Mountains greenstone celt flake fragment and two polished pebbles; these were probably used in smoothing and burnishing ceramic vessels made on the site. The polished pebbles, both made from local quartzite, are 29-53 $\mathrm{mm}$ in length and $24-29 \mathrm{~mm}$ in width. 


\section{Ceramic Sherds}

There are 485 ceramic sherds from plain ware, utility ware, and fine ware vessels in the 41HS144 collection at TARL (Table 1). About 78 percent of the sherds are from grog-tempered vessels, and the remaining 22 percent are from bone-tempered vessels. Utility ware sherds are more likely to be from bone-tempered vessels (30 percent) than are either the plain ware (13 percent) or fine ware (6 percent) sherds. Conversely, fine wares are disproportionally more commonly from grog-tempered vessels ( 94 percent) than are utility wares (70 percent). These differences between the wares likely are a product of their different intended functions.

Table 1. Ceramic sherd assemblage from $41 \mathrm{HS} 144$.

\begin{tabular}{|c|c|c|c|c|c|c|c|}
\hline \multirow[t]{2}{*}{ Ware } & \multicolumn{7}{|c|}{ Temper } \\
\hline & rim & $\begin{array}{l}\text { grog } \\
\text { body }\end{array}$ & base & rim & $\begin{array}{l}\text { bone } \\
\text { body }\end{array}$ & base & $\mathrm{N}$ \\
\hline Plain & 6 & 133 & 15 & 1 & 20 & 2 & 177 \\
\hline Utility & 24 & 169 & - & 6 & 76 & - & 275 \\
\hline Fine & 3 & 28 & - & - & 2 & - & 33 \\
\hline Totals & 33 & 330 & 15 & 7 & 98 & 2 & 485 \\
\hline
\end{tabular}

About 18 percent of the rims are from plain ware bowls and jars; only 7.5 percent of the rim sherds are from engraved fine ware vessels (carinated bowls) (see Table 1). Rim sherds from utility ware vessels (most likely primarily from jars) are by far the most common in the assemblage, comprising 75 percent of the sample of rim sherds.

The plain to decorated sherd ratio for the $41 \mathrm{HS} 144$ assemblage is a low 0.58 , indicating that the proportion of decorated sherds to plain sherds is considerable, presuming that the assemblage constitutes a representative sample of sherds from the site overall. More than 63 percent of all the sherds in the assemblage are decorated, and more than 82 percent of the rim sherds are from decorated vessels (see Table 1). Overall, utility ware sherds account for almost 90 percent of all the decorated sherds at 41HS144, as well as 91 percent of the decorated rim sherds.

The utility ware sherds are primarily from vessels decorated on the rim and/or the body with brushing marks, either as the sole form of decoration (71.6 percent of the utility ware sherds), or in combination with appliqued, incised, incised-punctated, punctated, or punctated-appliqued elements (Table 2). These latter sherds comprise another 17.4 percent of the 41HS144 utility wares.

Given the overall dominance of the sherds from vessels with brushed decorations, the other utility wares are not well represented in the 41HS144 assemblage (see Table 2): appliqued and appliqued-incised sherds represent 1.1 percent of the assemblage; incised sherds only 4.4 percent of the assemblage and incisedpunctated sherds another 0.7 percent; sherds from pinched vessels comprise 1.5 percent of the utility wares; and sherds from tool punctated sherds account for 3.3 percent of the utility ware assemblage.

Appliqued and appliqued-incised decorative elements occur on vessel bodies, in at least one case using a straight appliqued ridge to define a panel on the vessel body that has an incised decorative element (Table 3). The brushed rim and body sherds are likely from Bullard Brushed and Pease Brushed-Incised vessels (see Suhm and Jelks 1962:Plates 11 and 60). These vessels have horizontal, diagonal, and vertical brushing marks on the rim as well as the vessel body. Certainly the brushed-appliqued, brushed-incised (Figure 5e), brushedincised-punctated (Figure 5c-d), and brushed-punctated-appliqued sherds are from Pease Brushed-Incised vessels, but the brushed-punctated rim and body sherds (Figure 5f-h) may be from either utility ware type. 
Table 2. Utility ware decorative methods in the $41 \mathrm{HS} 144$ ceramic assemblage.

\begin{tabular}{lrrrr}
\hline Decorative method & Grog & Bone & N & Percent \\
\hline Appliqued & 2 & - & 2 & 0.7 \\
Appliqued-incised & - & 1 & 1 & 0.4 \\
Brushed & 142 & 55 & 197 & 71.6 \\
Brushed-appliqued & 3 & 3 & 7 & 2.5 \\
Brushed-incised & 5 & 4 & 8 & 2.9 \\
Brushed-incised-punctated & 1 & - & 5 & 1.8 \\
Brushed-punctated & 17 & - & 1 & 9.8 \\
Brushed-punctated-appliqued & 1 & 1 & 2 & 0.4 \\
Incised & 9 & 1 & 4 & 4.4 \\
Incised-punctated & 2 & 82 & 275 & 0.7 \\
Pinched & 3 & & 27.5 \\
Punctated, tool & 8 & & 3.3 \\
\hline Totals & 193 & & & 100.0 \\
\hline
\end{tabular}

Table 3. Decorative elements in utility ware sherds from 41HS144.

\begin{tabular}{lllll}
\hline Decorative method/ & \multicolumn{2}{c}{ Grog } & \multicolumn{2}{c}{ Bone } \\
Decorative element & Rim & Bim & Body & N \\
\hline
\end{tabular}

\section{Appliqued}

appliqued node

appliqued nodes in horizontal rows

\section{Appliqued-Incised}

straight appliqued ridge and diagonal incised line

\section{Brushed}

diagonal brushing marks

horizontal brushing marks

opposed brushing marks

overlapping brushing marks

parallel brushing marks

vertical brushing marks

\section{Brushed-Appliqued}

opposed brushed-straight appliqued fillet opposed brushed-straight appliqued ridge parallel brushed-straight appliqued fillet

\section{Brushed-Incised}

opposed brushed-vertical incised line parallel brushed-incised

$\begin{array}{ll}- & 1 \\ - & 1\end{array}$

$-$

$-$

1

$-$

$-$

1

1

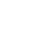

21

\section{$-$}

3

$4 \quad-$

-
$-\quad 8$

$\begin{array}{ll}- & 5\end{array}$

$-\quad 120$

11

$\begin{array}{ll}- & 1 \\ - & 1 \\ - & 1\end{array}$

$-$

$-$

$-$

$-$

-

2

1

3

3

$\begin{array}{ll}- & 1 \\ - & 4\end{array}$

$-$ 
Table 3. Decorative elements in utility ware sherds from 41HS144, cont.

\begin{tabular}{|c|c|c|c|c|c|}
\hline \multirow{2}{*}{$\begin{array}{l}\text { Decorative method/ } \\
\text { Decorative element }\end{array}$} & \multicolumn{2}{|c|}{ Grog } & \multicolumn{2}{|c|}{ Bone } & \multirow[b]{2}{*}{$\mathrm{N}$} \\
\hline & Rim & Body & Rim & Body & \\
\hline \multicolumn{6}{|l|}{ Brushed-Incised-Punctated } \\
\hline $\begin{array}{l}\text { diagonal brushed-incised and tool } \\
\text { punctated row under lip }\end{array}$ & 1 & - & - & - & 1 \\
\hline $\begin{array}{l}\text { horizontal lines on lower rim; tool } \\
\text { punctated row at rim-body } \\
\text { juncture; horizontal brushed on body }\end{array}$ & - & - & - & 2 & 2 \\
\hline $\begin{array}{l}\text { horizontal brushed-incised on body; } \\
\text { tool punctated row at rim-body } \\
\text { juncture }\end{array}$ & - & - & - & 1 & 1 \\
\hline $\begin{array}{l}\text { parallel brushed-incised with open } \\
\text { row of tool punctates }\end{array}$ & - & - & - & 1 & 1 \\
\hline \multicolumn{6}{|l|}{ Brushed-Punctated } \\
\hline $\begin{array}{l}\text { diagonal brushed and row of } \\
\text { tool punctates under lip }\end{array}$ & 2 & - & - & - & 2 \\
\hline $\begin{array}{l}\text { horizontal brushed and row of } \\
\text { tool punctates under lip }\end{array}$ & 6 & - & 2 & - & 8 \\
\hline $\begin{array}{l}\text { horizontal brushed and row of } \\
\text { tool punctates at rim-body } \\
\text { juncture }\end{array}$ & - & - & - & 2 & 2 \\
\hline $\begin{array}{l}\text { horizontal brushed-tool punctated } \\
\text { row through brushing }\end{array}$ & 1 & - & - & - & 1 \\
\hline $\begin{array}{l}\text { horizontal brushed and rows of } \\
\text { tool punctates through brushing }\end{array}$ & - & 1 & - & - & 1 \\
\hline $\begin{array}{l}\text { horizontal brushed on lower rim; } \\
\text { tool punctated row at rim-body } \\
\text { juncture and vertical brushed on body }\end{array}$ & - & 1 & - & - & 1 \\
\hline $\begin{array}{l}\text { opposed brushing and diagonal } \\
\text { opposed tool punctated rows }\end{array}$ & - & - & 1 & - & 1 \\
\hline $\begin{array}{l}\text { parallel brushed and row of tool } \\
\text { punctates through brushing }\end{array}$ & - & 2 & - & 4 & 6 \\
\hline $\begin{array}{l}\text { parallel brushed and tool and } \\
\text { linear tool punctated rows }\end{array}$ & - & 1 & - & - & 1 \\
\hline $\begin{array}{l}\text { tool punctated row at rim-body } \\
\text { juncture; vertical brushing on body }\end{array}$ & - & 3 & - & 1 & 4 \\
\hline \multicolumn{6}{|l|}{ Brushed-Punctated-Appliqued } \\
\hline $\begin{array}{l}\text { parallel brushed-straight } \\
\text { appliqued fillet and diagonal } \\
\text { rows of tool punctates }\end{array}$ & - & 1 & - & - & 1 \\
\hline
\end{tabular}


Table 3. Decorative elements in utility ware sherds from 41HS144, cont.

\begin{tabular}{|c|c|c|c|c|c|}
\hline \multirow{2}{*}{$\begin{array}{l}\text { Decorative method/ } \\
\text { Decorative element }\end{array}$} & \multicolumn{2}{|c|}{ Grog } & \multicolumn{2}{|c|}{ Bone } & \multirow[b]{2}{*}{$\mathrm{N}$} \\
\hline & Rim & Body & $\operatorname{Rim}$ & Body & \\
\hline \multicolumn{6}{|l|}{ Incised } \\
\hline cross-hatched lines & - & 1 & - & - & 1 \\
\hline horizontal lines & - & - & 1 & - & 1 \\
\hline parallel lines & - & 4 & - & 1 & 5 \\
\hline straight line & - & 4 & - & 1 & 5 \\
\hline \multicolumn{6}{|l|}{ Incised-Punctated } \\
\hline $\begin{array}{l}\text { diagonal incised lines, R-L, } \\
\text { and tool punctated row } \\
\text { below lip }\end{array}$ & 1 & - & - & - & 1 \\
\hline $\begin{array}{l}\text { diagonal opposed incised } \\
\text { lines (triangles) filled with } \\
\text { tool punctates; diagonal } \\
\text { row of tool punctates }\end{array}$ & - & 1 & - & - & 1 \\
\hline \multicolumn{6}{|l|}{ Pinched } \\
\hline parallel pinched ridges & - & 3 & - & 1 & 4 \\
\hline \multicolumn{6}{|l|}{ Punctated } \\
\hline linear tool punctated rows & 1 & - & - & - & 1 \\
\hline $\begin{array}{l}\text { tool punctated row on folded } \\
\text { over lip }\end{array}$ & 1 & - & - & - & 1 \\
\hline tool punctated row under lip & 3 & - & 1 & - & 4 \\
\hline tool punctated rows & 1 & 2 & - & - & 3 \\
\hline Totals & 24 & 169 & 6 & 76 & 275 \\
\hline
\end{tabular}

R-L, right to left (i.e., line begins on the right on the rim and ends on the left at the bottom of the rim)

Incised rim and body sherds are rather non-descript, with straight line and geometric elements (see Table 3). The one incised-punctated rim sherd is likely from a Maydelle Incised jar (Suhm and Jelks 1962:103), as is the grog-tempered body sherd. This sherd (see Figure 5b) has diagonal opposed incised lines forming triangle elements, the smaller of which is filled with rows of tool punctates. A diagonal row of tool punctations is opposite one of the triangle elements.

The four body sherds with parallel pinched ridges are from Killough Pinched jars (Suhm and Jelks 1962:91 and Plate 46f). All of the sherds with punctated decorations have rows of tool punctations (see Table 3), including one rim with rows of linear tool punctations (see Figure 5a). One rim has a row of tool punctations on an exterior folded lip, rather than below or under the lip.

Only 10.7 percent of the decorated sherds in the 41HS144 ceramic assemblage at TARL are from fine ware vessels (see Table 1). All of the fine ware sherds have engraved decorative elements (Table 4). None of the fine ware vessels had a red slip on interior and/or exterior vessel surfaces, and only one engraved sherd (3.0 percent of the sample), from a Washington Square Paneled vessel (Figure 6b), has a white kaolin clay pigment rubbed in the engraved lines. 


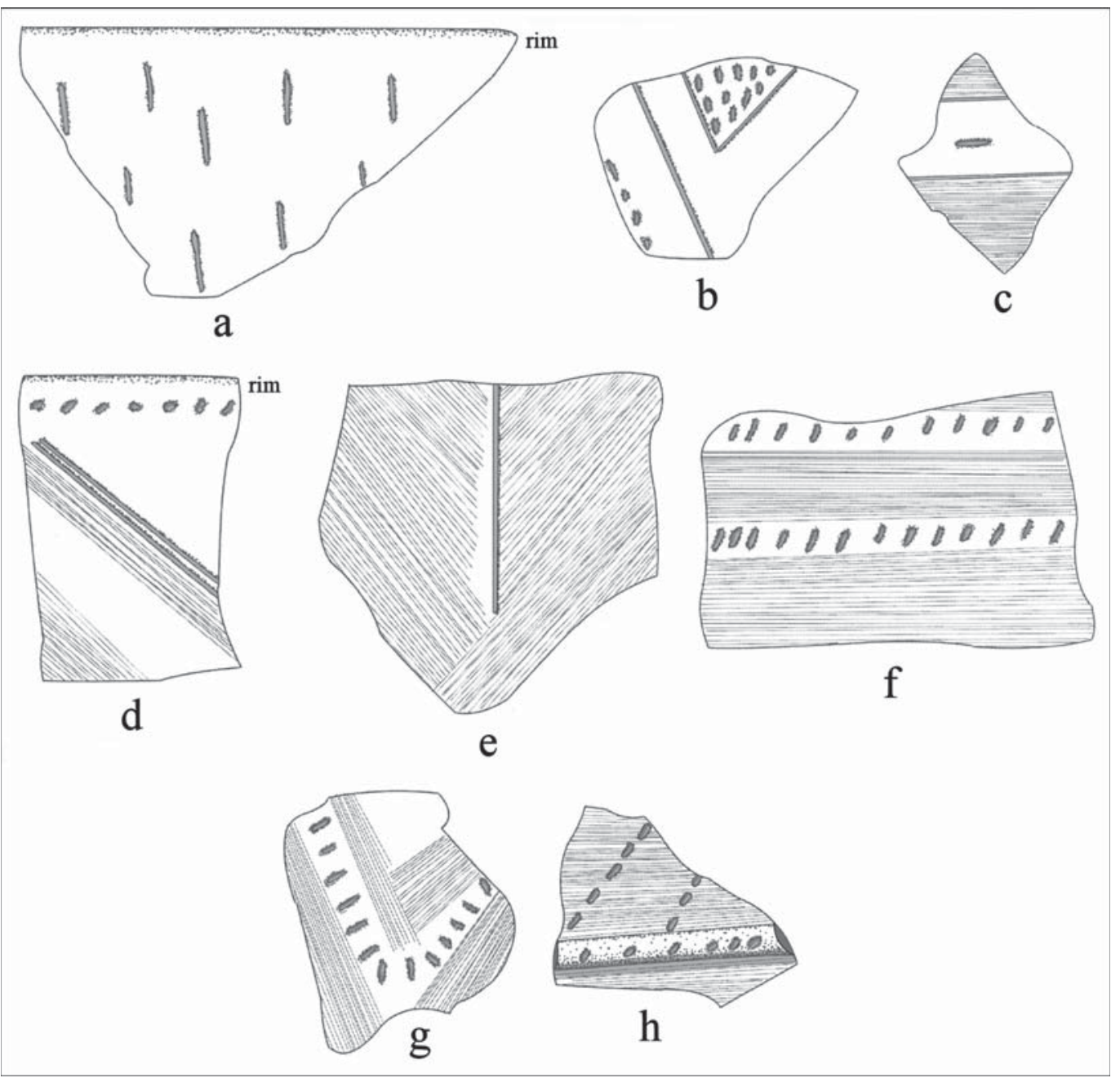

Figure 5. Decorative elements on utility ware sherds from 41HS144: a, linear punctated rim sherd; b, incised-punctated body sherd; c, brushed-incised-punctated body sherd; d, brushedincised-punctated rim sherd; e, brushed-incised body sherd; g; brushed-punctated rim sherd; $\mathrm{f}, \mathrm{h}$, brushed-punctated body sherd.

Table 4. Decorative elements in fine ware sherds from $41 \mathrm{HS} 144$.

\begin{tabular}{|c|c|c|c|c|c|}
\hline \multirow{2}{*}{$\begin{array}{l}\text { Decorative method/ } \\
\text { Decorative element }\end{array}$} & \multicolumn{2}{|c|}{ Grog } & \multicolumn{2}{|c|}{ Bone } & \multirow[b]{2}{*}{$\mathrm{N}$} \\
\hline & Rim & Body & $\operatorname{Rim}$ & Body & \\
\hline \multicolumn{6}{|l|}{ Engraved } \\
\hline concentric circles & - & 1 & - & - & 1 \\
\hline concentric circles and scroll fill zone & - & 1 & - & - & 1 \\
\hline curvilinear lines & - & 2 & - & - & 2 \\
\hline $\begin{array}{l}\text { curvilinear lines and curvilinear } \\
\text { hatched zones }\end{array}$ & - & 1 & - & - & 1 \\
\hline $\begin{array}{l}\text { curvilinear line and open pendant } \\
\text { triangles }\end{array}$ & - & 1 & - & - & 1 \\
\hline curvilinear lines and scroll fill zone & - & 1 & - & - & 1 \\
\hline curvilinear and vertical lines & - & 1 & - & - & 1 \\
\hline
\end{tabular}


Table 4. Decorative elements in fine ware sherds from 41HS144, cont.

\begin{tabular}{|c|c|c|c|c|c|}
\hline \multirow{2}{*}{$\begin{array}{l}\text { Decorative method/ } \\
\text { Decorative element }\end{array}$} & \multicolumn{2}{|c|}{ Grog } & \multicolumn{2}{|c|}{ Bone } & \multirow[b]{2}{*}{$\mathrm{N}$} \\
\hline & $\operatorname{Rim}$ & Body & $\operatorname{Rim}$ & Body & \\
\hline horizontal lines & 1 & 4 & - & 2 & 7 \\
\hline $\begin{array}{l}\text { horizontal and curvilinear lines } \\
\text { and SZ element }\end{array}$ & - & 1 & - & - & 1 \\
\hline horizontal and diagonal lines & - & 1 & - & - & 1 \\
\hline $\begin{array}{l}\text { horizontal lines, large open and } \\
\text { excised triangles and negative } \\
\text { ovals }\end{array}$ & 1 & - & - & - & 1 \\
\hline $\begin{array}{l}\text { horizontal, vertical, and oval } \\
\text { lines and hatched zone }\end{array}$ & - & 1 & - & - & 1 \\
\hline horizontal lines and hatched zone & - & 1 & - & - & 1 \\
\hline horizontal hatched zone & 1 & 1 & - & - & 2 \\
\hline slanted scroll and vertical lines & - & 1 & - & - & 1 \\
\hline $\begin{array}{l}\text { slanted scroll and excised } \\
\text { bracket }\end{array}$ & - & 1 & - & - & 1 \\
\hline straight line & - & 3 & - & - & 3 \\
\hline $\begin{array}{l}\text { Washington Square Paneled } \\
\text { (engraved zones with excised } \\
\text { punctates) }\end{array}$ & - & 6 & - & - & 6 \\
\hline Totals & 3 & 28 & - & 2 & 33 \\
\hline
\end{tabular}

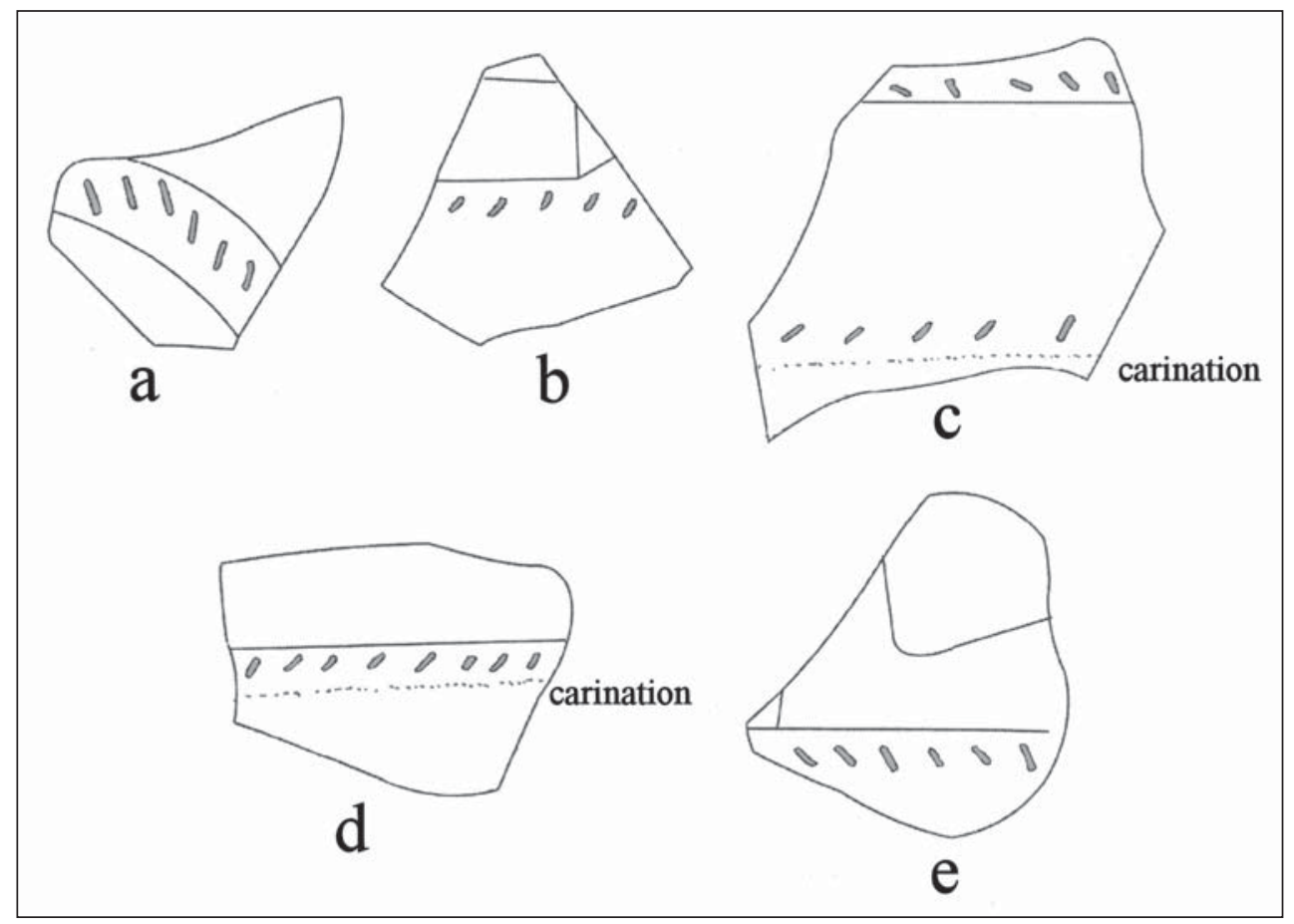

Figure 6. Washington Square Paneled sherds from 41HS144. 
The most recognizable of the fine ware sherds are the six body sherds from Washington Square Paneled carinated bowls. The rim panels of these carinated bowls have horizontal interlocking engraved scrolls with either upper, lower, and vertical engraved bands filled with excised tool punctates or single engraved lines with adjacent excised punctations (see Figure 6a-e). This particular decorative style on the rims from these vessels has a considerable distribution on Middle Caddo (ca. A.D. 1200-1450) period sites in the mid-Sabine River basin and tributaries (Gadus et al. 2006; Perttula 2014; Perttula and Nelson 2013; Perttula et al. 2014; Walters 2008) as well as contemporaneous Caddo sites in the Angelina River basin (see Hart 1982, 2014; Perttula 2008; Perttula et al. 2010).

One grog-tempered carinated bowl sherd may be from a Tyson Engraved carinated bowl (see Middlebrook 2014:91 and Figure 5), a late 14th to mid-15th century fine ware defined from sites in the Sabine and Angelina River basins. The sherd from 41HS144 has vertical biconcave pillars (or brackets) filled with closely-spaced engraved lines) and an SZ design (Figure 7j).

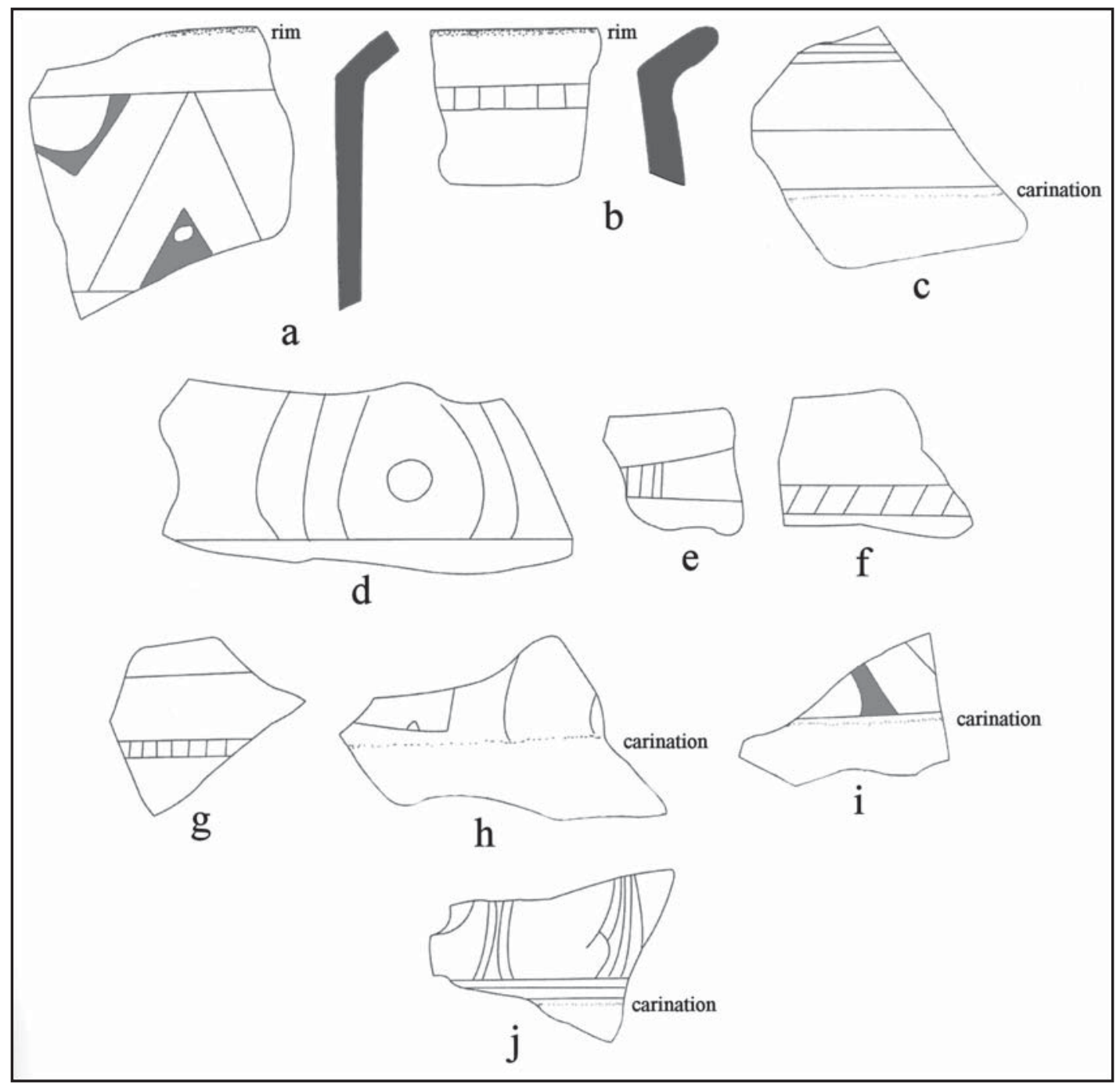

Figure 7. Decorative elements on selected engraved carinated bowl sherds from 41HS144.

Other engraved carinated bowl sherds from 41HS144 have narrow horizontal hatched zones (see Figure 7b, f-g), multiple sets of horizontal engraved lines (see Figure 7c), slanting scroll elements (see Figure 7e, h), and slanting scroll engraved elements with an excised bracket (see Figure 7i). One lower rim sherd has a series of concentric circles on the rim panel (see Figure 7d), and a rim sherd (with a distinctive exterior 
folded lip) and a body sherd have alternating large triangle (with a smaller excised triangle element within) and negative oval elements on the rim panel (see Figure 7a). There are no Ripley Engraved sherds represented in the carinated bowl sherds at 41HS144, and no other sherds with post-A.D. 1450 fine ware decorative elements known to be common in the middle Sabine River basin (see Fields and Gadus 2012:Table 6.17).

Five of the engraved sherds (15 percent) are from grog-tempered bottles. One is a Haley Engraved bottle with curvilinear engraved lines and excised pendant triangles (Figure 8a; see Suhm and Jelks 1962:61 and Plate 31), another has a set of open pendant triangles (Figure 8b), while the three other bottle sherds feature curvilinear lines, ovals, scroll fill zones, and narrow diagonal hatched zones (Figure 8c-d).

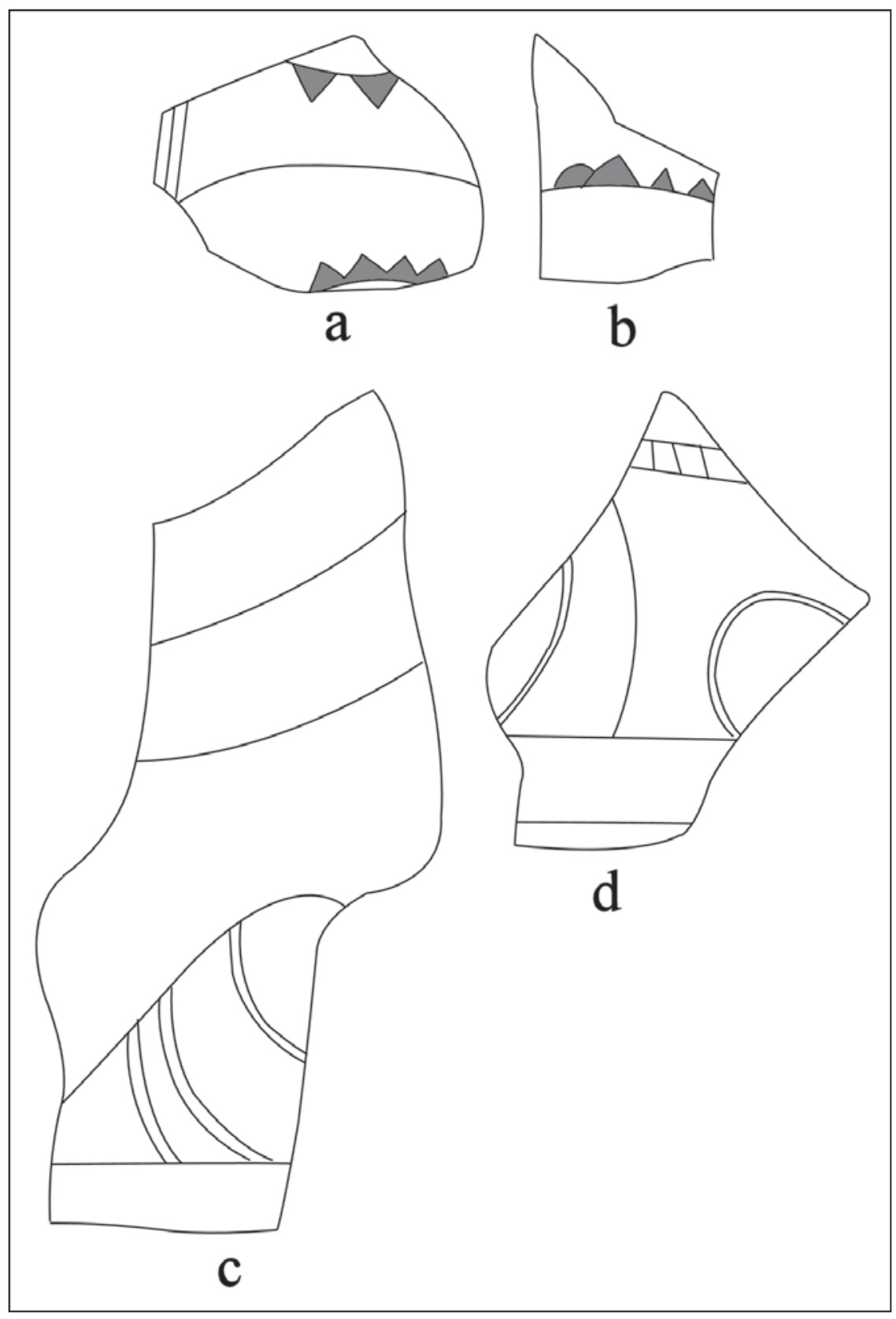

Figure 8. Decorative elements on selected engraved bottle sherds from 41HS144. 


\section{OTHER CLAY ARTIFACTS}

The other clay artifacts from 41HS144 include a clay coil (56 x $11 \mathrm{~mm}$ in length and width) and nine pieces of burned clay and daub. These latter pieces suggest that there was at least one burned thatch-covered Caddo structure in the archaeological deposits at the site.

\section{SUMMARY AND CONCLUSIONS}

Site 41HS144 was an intriguing ancestral Caddo settlement in the mid-Sabine River basin of East Texas. According to the collectors that worked at the site, it had both house structural and mortuary features (in a planned family cemetery), as well as large associated areas with habitation deposits. Unfortunately, the digging by the collectors was done in the absence of record keeping or photographic documentation, and only the sketchiest of information is available at TARL from the collectors about the cultural features on the site or their intra-site spatial relationships. Furthermore, no information is available on the kind and character of the funerary offerings that undoubtedly were present in most, if not all, burial features.

What is available about $41 \mathrm{HS} 144$ besides the limited records noted above is a collection of artifacts, primarily ceramic sherds, from the site. The provenience or context of these artifacts is not known, nor is it known if the artifact assemblage comprises a representative sample of the artifacts present in the site's habitation deposits. It is very doubtful, given the likely absence of screening by the collectors, that the artifact assemblage in the TARL collections from 41HS144 represents either a quantitatively or qualitatively reliable assemblage for comparative purposes. Nevertheless, ceramic stylistic information gleaned from the utility ware and fine ware sherds in the collection is informative in certain respects.

Specifically, grog-tempered and bone-tempered sherds from utility ware vessels dominate the 41HS144 ceramic assemblage, in particular high proportions of sherds from brushed, brushed-punctated, brushedappliqued, and brushed-incised Bullard Brushed and Pease Brushed-Incised vessels. A few sherds are from Maydelle Incised and Killough Pinched jars. The sherds from fine ware vessels are also distinctive, as there are sherds from Washington Square Paneled, Haley Engraved, and Tyson Engraved vessels, all considered ceramic types characteristic of the Middle Caddo period (ca. A.D. 1200-1450) in the middle Sabine River basin. Other fine ware sherds, although not typologically identifiable, in the assemblage have decorative elements commonly recognized in Middle Caddo period sites in the region, such as concentric circles and scroll fill zones; curvilinear lines and curvilinear hatched zones; open and excised pendant triangles on bottles; large open triangles, excised triangles, and negative ovals on rim panels; horizontal, vertical, and oval lines and a hatched zone; horizontal lines and a hatched zone; and a horizontal hatched zone.

The ceramic stylistic elements in the sherds from utility wares and fine ware vessels is sufficient to indicate that the ancestral Caddo settlement at 41HS144 took place sometime during the Middle Caddo period. Perhaps the occupation (and the associated cemetery) occurred during the late $14^{\text {th }}$-early $15^{\text {th }}$ century A.D., based on calibrated radiocarbon dates from the Musgano site (41RK19) (Perttula 2014), another Caddo site in the burgeoning Pine Tree Mound community in the middle Sabine River basin.

\section{ACKNOWLEDGMENTS}

I thank Jonathan Jarvis of the Texas Archeological Research Laboratory at The University of Texas at Austin for facilitating access to the collections and records from 41HS144. Lance Trask prepared the figures for this article. 


\section{REFERENCES CITED}

Fields, R. C. and E. F. Gadus (editors)

2012 Archeology of the Nadaco Caddo: The View from the Pine Tree Mound Site (41HS15), Harrison County, Texas. 2 Vols. Reports of Investigations No. 164. Prewitt and Associates, Inc., Austin.

Gadus, E. F., R. C. Fields, J. K. McWilliams, J. Dockall, and M. C. Wilder

2006 National Register Testing of Seven Prehistoric Sites in the Sabine Mine's Area Q, Harrison County, Texas. Reports of Investigations, Number 147. Prewitt and Associates, Inc., Austin.

Hart, J. P.

1982 An Analysis of the Aboriginal Ceramics from the Washington Square Mound Site, Nacogdoches County, Texas. Master's thesis, Department of Anthropology, Northeast Louisiana University, Monroe.

2014 An Analysis of the Aboriginal Ceramics from the Washington Square Mound Site, Nacogdoches County, Texas. Stephen F. Austin State University Press, Nacogdoches.

Middlebrook, T.

2014 Early European Descriptions of Hasinai Elites and Understanding Prehistoric Caddo Mortuary Practices in Shelby County, Texas. Bulletin of the Texas Archeological Society 85:83-110.

Perttula, T. K.

2014 The Caddo Archaeology of the Musgano Site (41RK19) in the Sabine River Basin of East Texas. Special Publication No. 28. Friends of Northeast Texas Archaeology, Pittsburg and Austin.

Perttula, T. K. (editor)

2008 Lake Naconiche Archeology, Nacogdoches County, Texas: Results of the Data Recovery Excavations at Five Prehistoric Archeological Sites. 2 Vols. Report of Investigations No. 60. Archeological \& Environmental Consultants, LLC, Austin.

Perttula, T. K. and B. Nelson

2013 Two Middle Caddo Period Habitation Sites and Cemeteries in the Sabine River Basin, Gregg County, Texas. Special Publication No. 27. Friends of Northeast Texas Archaeology, Pittsburg and Austin.

2014 Caddo Ceramic Vessels from the Loftis and Pearl Smith Sites in Harrison County, Texas. Journal of Northeast Texas Archaeology 45:63-66.

Perttula, T. K., R. Z. Selden, Jr., and B. Nelson

2014 Archaeological Investigations at the Wade (GC-38) and Estes (GC-49) Sites in the Sabine River Basin, Gregg County, Texas. Journal of Northeast Texas Archaeology 45:39-61.

Perttula, T. K., M. Walters, B. Nelson, B. Gonzalez, and R. Cast, with a contribution by R. G. Franciscus

2010 Documentation of Associated and Unassociated Caddo Funerary Objects in the Stephen F. Austin State University Collections, Nacogdoches, Texas. Stephen F. Austin State University Press, Nacogdoches.

Suhm, D. A. and E. B. Jelks (editors)

1962 Handbook of Texas Archeology: Type Descriptions. Special Publication No. 1, Texas Archeological Society, and Bulletin No. 4, Texas Memorial Museum, Austin. Reprinted in 2009, Gustav's Library, Davenport, Iowa.

Walters, M., with contributions from L. G. Cecil, L. S. Cummings, J. P. Dering, J. R. Ferguson, M. D. Glascock,

T. K. Perttula, L. Schniebs, H. J. Shafer, J. Todd, and C. P. Walker

2008 Life on Jackson Creek, Smith County, Texas: Archeological Investigations of a 14th Century Caddo Domicile at the Leaning Rock Site (41SM325). Caddo Archeology Journal 17:1-114. 